\title{
HUBUNGAN ANTARA LIMA DIMENSI MUTU PELAYANAN RAWAT JALAN DENGAN KEPUASAN PASIEN
}

\author{
Mokh Firman Ismana*
}

\begin{abstract}
ABSTRAK
Kepuasan pasien merupakan merupakan tingkat kepuasan dari persepsi pasien terhadap layanan kesehatan dan merupakan salah satu indikator kinerja. Apabila pasien menunjukan hal - hal yang bagus mengenai layanan kesehatan dan pasien mengindikasikan dengan perilaku yang positif maka akan dapat mengambil kesimpulan bahwa pasien merasa puas terhadap layanan tersebut. Penelitian ini bertujuan untuk mengetahui hubungan antara lima dimensi mutu pelayanan rawat jalan dengan kepuasan pasien di RSUD Arjawinangun Kabupaten Cirebon Tahun 2015. Jenis penelitian deskriptik analitik dengan desain Cross Sectional. Populasi dalam penelitian ini adalah jumlah seluruh pasien yang berobat ke rawat jalan RSUD Arjawinangun pada bulan Januari tahun 2015 sebanyak 9.707 pasien. Jumlah sampel sebanyak 385 pasien yang diambil secara Accidental Sampling. Data dianalisa secara statistic menggunakan uji Chi Square pada tingkat kemaknaan 5\% (0,05). Variabel yang diteliti yaitu variabel dependen: kepuasan pasien, variabel independen: Bukti Fisik (Tangibles), Kehandalan (Reliability), Ketanggapan (Responsiveness), Jaminan (Assurance), Dan Empati (Empathy). Hasil penelitian ini menunjukan ada hubungan yang bermakna antara Bukti Fisik (Tangibles) dengan kepuasan pasein $(\mathrm{p}=0,034)$, ada hubungan yang bermakna antara Kehandalan (Reliability) dengan kepuasan pasein $(\mathrm{p}=0,000)$, ada hubungan yang bermakna antara Ketanggapan (Responsiveness) dengan kepuasan pasein ( $\mathrm{p}=0,000)$, ada hubungan yang bermakna antara Jaminan (Assurance) dengan kepuasan pasein $(\mathrm{p}=0,000)$, ada hubungan yang bermakna antara Empati (Empathy) dengan kepuasan pasein $(\mathrm{p}=0,000)$.
\end{abstract}

Kata Kunci: Kepuasan Pasien, Lima dimensi mutu

\begin{abstract}
Patient's satisfaction is the satisfaction level of the patient's perception of the health services and is one of the performance indicators. If the patients shows the good things about the health care service and the patients indicated by the positive behavior will be able to infer that patients are satisfied with the health care service. This research aimed to determine the relationship between the five dimensions of quality of outpatient care with patient's satisfaction in RSUD Arjawinangun Kabupaten Cirebon 2015. The type of this research is descriptive analytic with Cross Sectional Design. Population in this research is the total number of outpatients treated at RSUD Arjawinangun Kabupaten Cirebon through Januari 2015 as many as 9707 patients. The total sample of 385 patients were taken by accidental sampling. Data were analyzed statiscally using Chi-squared test at 5\% (0.05) significance level. The dependent variable analyzed in this research is patient's satisfaction and the Independent variable in this research are Tangibles, Realiability, Responsiveness, Assurance, and Empathy. Judge from the analysis above, we conclude that the result of this research showed the relationship between Tangibles with patient's satisfaction $(p=0.034)$. There is relationship between Reliability with patient's satisfaction $(p=0.00)$. There is relationship between Responsiveness with patient's satisfaction $(p=0.00)$. The relationship between Assurance with patient's satisfaction is also influence with $p=0.00$, and the last of variable, there is relationship between empathy with patient's satisfaction $(p=0.00)$. The result of this research can be followed up by efforts to improve the Tangibles, Reliability, Responsiveness, Assurance, and Empathy by providing technical training to every officer to increase the ability to carry out the services.
\end{abstract}

Key Word : Patient's Satisfaction, Five dimensions of quality

\footnotetext{
* Staf Pengajar Program Studi S1 Keperawatan STIKes Cirebon
} 


\section{PENDAHULUAN}

Rumah Sakit merupakan salah satu lembaga yang bergerak dibidang pelayanan jasa kesehatan dengan tanggung jawab memberikan pengobatan, memberikan perawatan, mengusahakan kesembuhan dan kesehatan pasien, serta mengupayakan pendidikan hidup sehat bagi masyarakat. Pengertian Rumah Sakit adalah institusi pelayanan kesehatan yang menyelenggarakan pelayanan kesehatan perorangan secara paripurna yang menyediakan pelayanan rawat inap, rawat jalan, dan gawat darurat. Rumah Sakit umum adalah Rumah Sakit yang memberikan pelayanan kesehatan pada semua bidang dan jenis penyakit. ${ }^{1}$

Salah satu indikator keberhasilan pelayanan kesehatan adalah kepuasan pasien. Kepuasaan pasien merupakan cerminan dari kualitas pelayanan kesehatan yang mereka terima. Mutu pelayanan kesehatan adalah menunjukkan pada tingkat kesempurnaan pelayanan kesehatan dalam menimbulkan rasa puas pada diri setiap pasien. Makin sempurna kepuasaan tersebut, makin baik pula mutu pelayanan kesehatan. ${ }^{2}$

Berry, Parasuraman, dan Zeithaml mengidentifikasi adanya kesenjangan antara persepsi konsumen dan persepsi penyedia jasa pelayanan kesehatan yang mengakibatkan kegagalan penyampaian jasa yang berkualitas. ${ }^{3}$

Langkah pertama untuk mengatasi kesenjangan antara persepsi pasien dan persepsi penyedia jasa pelayanan kesehatan adalah mengidentifikasi atau mengenal kebutuhan pasien dan faktor - faktor apa saja yang berpengaruh terhadap mutu pelayanan yang diterimanya. Dengan mengenal hal tersebut maka akan memberikan suatu pemahaman yang lebih baik mengenai mutu pelayanan yang telah diterima oleh pasien sehingga Rumah Sakit akhirnya dapat memahami bagaimana gambaran kepuasan pasien terhadap pelayanan yang telah diberikan. Menurut Parasuraman ada lima dimensi mutu pelayanan yang menjadi kunci dalam memberikan pelayanan berkualitas kepada konsumen yaitu Bukti Fisik (Tangible), Kehandalan (Reliability), Ketanggapan (Responsiveness), Jaminan (Assuranc), dan Empati (Empaty). ${ }^{4}$

Rumah Sakit Umum Daerah (RSUD) Arjawinangun merupakan salah satu Rumah Sakit milik Pemerintah Daerah Kabupaten Cirebon yang berkedudukan di Kecamatan Arjawinangun. Pada tahun 2010 ditetapkan sebagai Badan Layanan Umum Daerah (BLUD) secara penuh yang bertujuan meningkatkan pelayanan kepada masyarakat dalam rangka memajukan kesejahteraan umum dan mencerdaskan kehidupan bangsa dengan memberikan fleksibilitas dalam pengelolaan keuangan berdasarkan prinsip ekonomi dan produktivitas dan penerapan praktik bisnis yang sehat. ${ }^{5}$ Dengan demikian Rumah Sakit di tuntut untuk memberikan pelayanan kesehatan yang bermutu, sehingga akan berujung pada kepuasan pasien.

Berdasarkan data jumlah kunjungan pasien rawat jalan di RSUD Arjawinangun terus mengalami kenaikan sejak tahun 2010 sampai tahun 2014 terus mengalami kenaikan (tahun 2010 sebanyak 77.058, tahun 2011 sebanyak 76.425, tahun 2012 sebanyak 80.594, tahun 2013 sebanyak 94.004 dan tahun 2014 sebanyak 101.648). Walaupun terjadi sedikit penurunan dari tahun 2010 ke 2011. Banyaknya pasien yang memanfaatkan fasilitas pelayanan rawat jalan tersebut sangat terkait dengan kepuasan yang diperolehnya. Kepuasan pasien merupakan keseimbangan antara harapan, persepsi dan yang dialami. ${ }^{6}$

Dalam kurun waktu tiga tahun tersebut manajemen Rumah Sakit RSUD Arjawinangun banyak melakukan perbaikan dan peningkatkan kualitas dan mutu pelayanan rawat jalan. Dalam hal layanan kesehatan, manajemen melakukan pengembangan dengan dengan menambah layanan klinik spesialis antara lain klinik Kulit dan Kelamin, Klinik HIV/AIDS, dan klinik Psikiatri. Dalam hal sumber daya manusia, manajemen Rumah Sakit menambah jumlah dokter spesialis yang melaksanakan pelayanan di poliklinik, dan melakukan pelatihan teknis kepada para petugas di rawat jalan. Dari segi sarana prasarana, untuk kenyamanan 
pasien saat menunggu pendaftaran dan menunggu giliran mendapatkan pelayanan dari dokter maupun farmasi, manajemen Rumah Sakit memasang layar televisi dan menyediakan air minum secara gratis di beberapa titik disekitar ruang tunggu pasien.

Akan tetapi berdasarkan pendapat, saran, dan masukan dari 98 orang pasien dan keluarga pasien melalui kotak saran yang dikelolakan oleh Bagian Humas RSUD Arjawinangun pada periode Juli sampai dengan September 2014, masih banyak pasien yang mengeluhkan kurang baiknya pelayanan yang mereka di terima. ${ }^{7}$ Tujuan dalam penelitian ini untuk mengetahui Hubungan antara lima dimensi mutu pelayanan rawat jalan dengan kepuasan pasien di RSUD Arjawinangun Kabupaten Cirebon Tahun 2015.

\section{METODE PENELITIAN}

Dalam penelitian ini penulis menggunakan jenis rancangan deskriptif analitik dengan pendekatan Cross Sectional. ${ }^{8}$ Variabel yang dikaji dalam penelitian ini adalah variabel bebas (independent variabel) meliputi bukti fisik kehandalan, ketanggapan, jaminan, dan empati.dan variabel terikat (dependent variabel) meliputi kepuasan pasien. Populasi dalam penelitian ini adalah pasien atau keluarga pasien yang berkunjung ke pelayanan rawat jalan RSUD Arjawinangun sebanyak 9.707 orang. Berdasarkan pengambilan besar sampel didapatkan sampel sebanyak 385 pasien. Pengambilan sampel dari populasi dilakukan dengan metode Accidental Sampling. ${ }^{8}$

Dalam penelitian ini kuesioner yang digunakan mengadopsi dari Faizal Maulidhany Rarin dengan judul Analisis Kepuasan Pelanggan Terhadap Pelayanan Pasien Rawat Jalan Di Rumah Sakit Islam Hidayatullah Yogyakarta. ${ }^{9}$ Metode pengumpulan data yang digunakan dengan menggunakan wawancara. Sedangkan instrumen yang digunakan adalah kuesioner.

Analisis data dilakukan secara univariat dan bivariat, analisa univariat merupakan suatu analisis untuk mendeskripsikan masing-masing variabel yang diteliti. Analisa ini bertujuan untuk mengetahui gambaran distribusi frekuensi dan proporsi dari variabel dependent dan independent yang ada pada penelitian ini yaitu variabel kehandalan, ketanggapan, jaminan, empati, dan bukti fisik dan kepuasan pasien umum. Analisa bivariat dilakukan untuk melihat hubungan antara faktor independent dan faktor dependent. Variabel independent terdiri dari kehandalan, ketanggapan, jaminan, empati, dan bukti fisik, Sedangkan variabel dependent yaitu kepuasan pasien umum. Analisis menggunakan uji statistik Chi Square dengan $\alpha=0,05$.

\section{HASIL PENELITIAN}

\section{Kepuasan Pasien Rawat Jalan}

Hasil penelitian menunjukkan bahwa kepuasan pasien rawat jalan yang menyatakan kurang puas sebanyak 116 pasien $(30,1 \%)$ dan yang menyatakan puas sebanyak 269 pasien $(69,9 \%)$.

\section{Bukti Fisik}

Hasil penelitian menunjukkan bahwa bukti fisik pelayanan rawat jalan, pasien yang menyatakan kurang baik sebanyak 100 pasien $(26,0 \%)$ dan pasien yang menyatakan baik sebanyak 285 pasien $(74,0 \%)$.

\section{Kehandalan}

Hasil penelitian menunjukkan bahwa kehandalan petugas dalam memberikan pelayanan rawat jalan, pasien yang menyatakan kurang baik sebanyak 112 pasien $(29,1 \%)$ dan pasien yang menyatakan baik sebanyak 273 pasien $(70,9 \%)$. 


\section{Ketanggapan}

Hasil penelitian menunjukkan bahwa ketanggapan petugas dalam memberikan pelayanan rawat jalan, pasien yang menyatakan kurang baik sebanyak 134 pasien $(34,8 \%)$ dan pasien yang menyatakan baik sebanyak 251 pasien $(65,2 \%)$.

\section{Jaminan}

Hasil penelitian menunjukkan bahwa jaminan terhadap pasien dalam memberikan pelayanan rawat jalan, pasien yang menyatakan kurang baik sebanyak 157 pasien $(40,8 \%)$ dan pasien yang menyatakan baik sebanyak 228 pasien $(59,2 \%)$.

\section{Empathy}

Hasil penelitian menunjukkan bahwa empati petugas kepada pasien dalam memberikan pelayanan rawat jalan, pasien yang menyatakan kurang baik sebanyak 223 pasien $(57,9 \%)$ dan pasien yang menyatakan baik sebanyak 162 pasien $(42,1 \%)$.

\section{Hubungan antara Dimensi Bukti Fisik dengan Kepuasan Pasien}

Tabel 1 Hubungan antara Dimensi Bukti Fisik dengan Kepuasan Pasien

\begin{tabular}{|c|c|c|c|c|c|c|c|}
\hline \multirow{3}{*}{ Bukti Fisik } & \multicolumn{4}{|c|}{ Kepuasan } & & & \multirow{2}{*}{$\mathrm{P}$ value } \\
\hline & \multicolumn{2}{|c|}{ Kurang Puas } & \multicolumn{2}{|c|}{ Puas } & \multicolumn{2}{|c|}{ Total } & \\
\hline & $\mathrm{n}$ & $\%$ & $\mathrm{n}$ & $\%$ & $\mathrm{n}$ & $\%$ & \multirow{4}{*}{0,025} \\
\hline Kurang Baik & 39 & 39,0 & 61 & 61,0 & 100 & 100,0 & \\
\hline Baik & 77 & 27,0 & 208 & 73,0 & 285 & 100,0 & \\
\hline Total & 116 & 30,1 & 269 & 69,9 & 385 & 100,0 & \\
\hline
\end{tabular}

Tabel 1 menunjukkan bahwa pasien rawat jalan di RSUD Arjawinangun Kabupaten Cirebon Tahun 2015 yang menyatakan kurang baik tentang bukti fisik sebagian besar menyatakan puas terhadap pelayanan rawat jalan yaitu sebanyak 61 pasien $(61,0 \%)$ dan pasien yang menyatakan baik sebagian besar juga menyatakan puas atas pelayanan rawat jalan yaitu sebanyak 208 pasien $(73,0 \%)$.

Dari hasil statistik diperoleh $P=0,034(\mathrm{p} \leq 0,05)$ yang menunjukan bahwa Ho = ditolak artinya ada hubungan yang bermakna antara dimensi bukti fisik dengan kepuasan pasien dalam pelayanan rawat jalan di RSUD Arjawinangun Kabupaten Cirebon Tahun 2015.

\section{Hubungan antara Dimensi Kehandalan dengan Kepuasan Pasien}

Tabel 2 Hubungan antara Dimensi Kehandalan dengan Kepuasan Pasien

\begin{tabular}{|c|c|c|c|c|c|c|c|}
\hline \multirow{3}{*}{ Kehandalan } & \multicolumn{4}{|c|}{ Kepuasan } & \multirow{2}{*}{\multicolumn{2}{|c|}{ Total }} & \multirow{3}{*}{$\mathrm{P}$ value } \\
\hline & \multicolumn{2}{|c|}{ Kurang Puas } & \multicolumn{2}{|c|}{ Puas } & & & \\
\hline & $\mathrm{n}$ & $\%$ & $\mathrm{n}$ & $\%$ & $\mathrm{n}$ & $\%$ & \\
\hline Kurang Baik & 99 & 88,4 & 13 & 11,6 & 112 & 100,0 & \multirow{3}{*}{0,000} \\
\hline Baik & 17 & 6,2 & 256 & 93,8 & 273 & 100,0 & \\
\hline Total & 116 & 30,1 & 269 & 69,9 & 385 & 100,0 & \\
\hline
\end{tabular}


Tabel 2 menunjukkan bahwa pasien rawat jalan di RSUD Arjawinangun Kabupaten Cirebon Tahun 2015 yang menyatakan kurang baik tentang kehandalan pelayanan sebagian besar juga menyatakan kurang puas terhadap pelayanan rawat jalan yang mereka terima yaitu sebanyak 99 pasien $(88,4 \%)$ dan pasien yang menyatakan baik sebagian besar menyatakan puas atas pelayanan rawat jalan yaitu sebanyak 256 pasien $(93,8 \%)$.

Dari hasil statistik diperoleh $P=0,000(\mathrm{p} \leq 0,05)$ yang menunjukan bahwa Ho $=$ ditolak artinya ada hubungan yang bermakna antara dimensi kehandalan dengan kepuasan pasien dalam pelayanan rawat jalan di RSUD Arjawinangun Kabupaten Cirebon Tahun 2015.

\section{Hubungan antara Dimensi Ketanggapan dengan Kepuasan Pasien}

Tabel 3 Hubungan antara Dimensi Ketanggapan dengan Kepuasan Pasien

\begin{tabular}{|c|c|c|c|c|c|c|c|}
\hline \multirow{3}{*}{ Ketanggapan } & \multicolumn{4}{|c|}{ Kepuasan } & \multirow{2}{*}{\multicolumn{2}{|c|}{ Total }} & \multirow{3}{*}{$\mathrm{P}$ value } \\
\hline & \multicolumn{2}{|c|}{ Kurang Puas } & \multicolumn{2}{|c|}{ Puas } & & & \\
\hline & $\mathrm{n}$ & $\%$ & $\mathrm{n}$ & $\%$ & $\mathrm{n}$ & $\%$ & \\
\hline Kurang Baik & 100 & 74,6 & 34 & 25,5 & 134 & 100,0 & \multirow{3}{*}{0,000} \\
\hline Baik & 16 & 6,4 & 235 & 93,6 & 251 & 100,0 & \\
\hline Total & 116 & 30,1 & 269 & 69,9 & 385 & 100,0 & \\
\hline
\end{tabular}

Tabel 3 menunjukkan bahwa pasien rawat jalan di RSUD Arjawinangun Kabupaten Cirebon Tahun 2015 yang menyatakan kurang baik tentang ketanggapan pelayanan rawat jalan sebagian besar dari mereka juga menyatakan kurang puas terhadap pelayanan rawat jalan yang diterima yaitu sebanyak 100 pasien $(74,6 \%)$ dan pasien yang menyatakan baik sebagian besar juga menyatakan puas atas pelayanan yang diterima yaitu sebanyak 235 pasien $(93,6 \%)$.

Dari hasil statistik diperoleh $P=0,000(\mathrm{p} \leq 0,05)$ yang menunjukan bahwa Ho $=$ ditolak artinya ada hubungan yang bermakna antara dimensi ketanggapan dengan kepuasan pasien dalam pelayanan rawat jalan di RSUD Arjawinangun Kabupaten Cirebon Tahun 2015.

\section{Hubungan antara Dimensi Jaminan dengan Kepuasan Pasien.}

Tabel 4 Hubungan antara Dimensi Jaminan dengan Kepuasan Pasien

\begin{tabular}{|c|c|c|c|c|c|c|c|}
\hline \multirow{3}{*}{ Jaminan } & \multicolumn{4}{|c|}{ Kepuasan } & \multirow{2}{*}{\multicolumn{2}{|c|}{ Total }} & \multirow{3}{*}{$\mathrm{P}$ value } \\
\hline & \multicolumn{2}{|c|}{ Kurang Puas } & \multicolumn{2}{|c|}{ Puas } & & & \\
\hline & $\mathrm{n}$ & $\%$ & $\mathrm{n}$ & $\%$ & $\mathrm{n}$ & $\%$ & \\
\hline Kurang Baik & 83 & 52,9 & 74 & 47,1 & 157 & 100,0 & \multirow{3}{*}{0,000} \\
\hline Baik & 33 & 14,5 & 195 & 85,5 & 228 & 100,0 & \\
\hline Total & 116 & 30,1 & 269 & 69,9 & 385 & 100,0 & \\
\hline
\end{tabular}

Tabel 4 menunjukkan bahwa pasien rawat jalan di RSUD Arjawinangun Kabupaten Cirebon Tahun 2015 yang menyatakan kurang baik tentang jaminan pelayanan rawat jalan sebagian besar dari mereka juga menyatakan kurang puas terhadap pelayanan rawat jalan yang diterima yaitu sebanyak 83 pasien $(52,9 \%)$ dan pasien yang menyatakan baik sebagian 
besar juga menyatakan puas atas pelayanan yang diterima yaitu sebanyak 195 pasien $(85,5 \%)$.

Dari hasil statistik diperoleh $P=0,000(\mathrm{p} \leq 0,05)$ yang menunjukan bahwa Ho = ditolak artinya ada hubungan yang bermakna antara dimensi jaminan dengan kepuasan pasien dalam pelayanan rawat jalan di RSUD Arjawinangun Kabupaten Cirebon Tahun 2015.

Hubungan antara Dimensi Empati dengan Kepuasan Pasien.

Tabel 5 Hubungan antara Dimensi Empati dengan Kepuasan Pasien

\begin{tabular}{lccccccc}
\hline \multirow{2}{*}{ Empati } & \multicolumn{4}{c}{ Kepuasan } & & \multirow{2}{*}{ Total } & P value \\
\cline { 2 - 6 } & \multicolumn{2}{c}{ Kurang Puas } & \multicolumn{2}{c}{ Puas } & & \\
\cline { 2 - 6 } Kurang Baik & $\mathrm{n}$ & $\%$ & $\mathrm{n}$ & $\%$ & $\mathrm{n}$ & $\%$ \\
Baik & 18 & 11,1 & 144 & 88,9 & 162 & 100,0 & 0,000 \\
\hline \multicolumn{1}{c}{ Total } & 116 & 30,1 & 269 & 69,9 & 385 & 100,0 & \\
\hline
\end{tabular}

Tabel 5 menunjukkan bahwa pasien rawat jalan di RSUD Arjawinangun Kabupaten Cirebon Tahun 2015 yang menyatakan kurang baik tentang empati yang diberikan petugas pelayanan rawat jalan sebagian besar dari mereka menyatakan puas terhadap pelayanan rawat jalan yang diterima yaitu sebanyak 125 pasien $(56,1 \%)$ dan pasien yang menyatakan baik sebagian besar juga menyatakan puas atas pelayanan yang diterima yaitu sebanyak 144 pasien $(88,9 \%)$.

Dari hasil statistik diperoleh $P=0,000(\mathrm{P} \leq 0,05)$ yang menunjukan bahwa Ho = ditolak artinya ada hubungan yang bermakna antara dimensi empati dengan kepuasan pasien dalam pelayanan rawat jalan di RSUD Arjawinangun Kabupaten Cirebon Tahun 2015.

\section{PEMBAHASAN}

\section{Hubungan antara Dimensi Bukti Fisik dengan Kepuasan Pasien}

Dari hasil statistik diperoleh $P=0,034(\mathrm{P}<0,05)$ yang menunjukan bahwa Ho = ditolak artinya ada hubungan yang bermakna antara dimensi bukti fisik dengan kepuasan pasien dalam pelayanan rawat jalan di RSUD Arjawinangun Kabupaten Cirebon Tahun 2015.

Bukti fisik merupakan bukti langsung yang meliputi fasilitas fisik, yang mencakup kebersihan, kerapian dan kenyamanan ruangan, penataan eksterior dan interior, kelengkapan, kesiapan, kebersihan kemutakhiran alat - alat yang dipakai, serta kerapian dan kebersihan penampilan petugas.

Hasil penelitian di atas sesuai dengan pendapat Kotler bahwa kepuasan sebagai respon dari pemenuhan harapan dan kebutuhan konsumen. Respon ini sebagai hasil dari penilaian konsumen bahwa produk atau pelayanan sudah memberikan tingkat pemenuhan kenikmatan. Pendapat ini juga dikemukakan oleh Tjiptono yang mengemukakan bahwa tingkat pemenuhan kenikmatan dan harapan ini dapat lebih atau kurang. Ketidakpuasan merupakan respon pelanggan sebagai hasil dan evaluasi ketidaksesuaian kinerja atau tindakan yang dirasakan sebagai akibat dari tidak terpenuhinya harapan. Kepuasan merupakan persepsi yang dirasakan oleh individu ketika harapan dan kebutuhannya dapat dipenuhi oleh individu atau faktor lainnya. Pasien merupakan salah satu individu yang memerlukan penanganan dengan kemampuan lebih dari petugas kesehatan. Ketika fasilitas yang ada di pelayanan rawat jalan sesuai dengan yang dikehendaki oleh pasien maka pasien akan merasa puas dengan apa yang mereka terima. ${ }^{10}$ 


\section{Hubungan antara Dimensi Kehandalan dengan Kepuasan Pasien}

Hasil penelitian menunjukkan bahwa pasien rawat jalan di RSUD Arjawinangun Kabupaten Cirebon Tahun 2015 yang menyatakan kurang baik tentang kehandalan pelayanan sebagian besar juga menyatakan kurang puas terhadap pelayanan rawat jalan yang mereka terima yaitu sebanyak 99 pasien $(88,4 \%)$ dan pasien yang menyatakan baik sebagian besar menyatakan puas atas pelayanan rawat jalan yaitu sebanyak 256 pasien (93,8\%). Dari hasil uji statistik menunjukan bahwa ada hubungan yang bermakna antara dimensi kehandalan dengan kepuasan pasien dalam pelayanan rawat jalan di RSUD Arjawinangun Kabupaten Cirebon Tahun 2015.

Hasil penelitian serupa yang dilakukan oleh Penelitian Laila Khairani dengan judul Faktor - Faktor Yang Mempengaruhi Kepuasan Pasien Rawat Jalan RSUD Pasaman Barat Tahun 2014. Hasil penelitiannya menunjukan untuk variable kehandalan, $(67,4 \%)$ responden menyatakan persepsi kehandalan petugas kesehatan baik dan $(32,6 \%)$ menyatakan persepsi kehandalan petugas kesehatan tidak baik. ${ }^{11}$ Dan penelitian Fuzna Elsa Ulinuha (2014) dengan judul kepuasan pasien BPJS (Badan Penyelenggara Jaminan Sosial) terhadap pelayanan di Unit Rawat Jalan (URJ) Rumah Sakit Permata Medika Semarang Tahun 2014. Mendapatkan kesimpulan pada Reability/keandalan beberapa responden puas dengan tindakan yang cepat dan tepat terhadap pemeriksaan, pengobatan dan perawatan sebesar $56,56 \% .^{12}$

\section{Hubungan antara Dimensi Ketanggapan dengan Kepuasan Pasien}

Hasil penelitian menunjukkan bahwa pasien rawat jalan di RSUD Arjawinangun Kabupaten Cirebon Tahun 2015 yang menyatakan kurang baik tentang ketanggapan pelayanan rawat jalan sebagian besar dari mereka juga menyatakan kurang puas terhadap pelayanan rawat jalan yang diterima yaitu sebanyak 100 pasien $(74,6 \%)$ dan pasien yang menyatakan baik sebagian besar juga menyatakan puas atas pelayanan yang diterima yaitu sebanyak 235 pasien $(93,6 \%)$. Dari hasil uji statistik menunjukan bahwa ada hubungan yang bermakna antara dimensi ketanggapan dengan kepuasan pasien dalam pelayanan rawat jalan di RSUD Arjawinangun Kabupaten Cirebon Tahun 2015.

Hasil penelitian serupa yang dilakukan oleh Penelitian Laila Khairani dengan judul Faktor - Faktor Yang Mempengaruhi Kepuasan Pasien Rawat Jalan RSUD Pasaman Barat Tahun 2014. Hasil penelitiannya menunjukan untuk variabel ketanggapan $(58,7 \%)$ responden menyatakan persepsi ketanggapan petugas kesehatan baik dan $(41,3 \%)$ responden menyatakan persepsi ketanggapan petugas tidak baik. ${ }^{11}$ Dan penelitian Fuzna Elsa Ulinuha (2014) dengan judul Kepuasan Pasien BPJS (Badan Penyelenggara Jaminan Sosial) Terhadap Pelayanan di Unit Rawat Jalan (URJ) Rumah Sakit Permata Medika Semarang Tahun 2014. Mendapatkan kesimpulan pada variabel responsiveness/daya tanggap responden puas dalam dokter dan perawat yang memberikan reaksi cepat dan tanggap sebesar 54,54\% dan responden tidak puas dalam aspek kesiagaan petugas kesehatan untuk membantu pasien sebesar $10,10 \% .^{12}$

Hasil penelitian ini menyatakan bahwa ada hubungan antara dimensi ketanggapan dengan kepuasan pasien rawat jalan di RSUD Arjawinangun Kabupaten Cirebon. Asumsi peneliti mengenai hal tersebut bahwa ketanggapan petugas harus lebih ditingkatkan karena sebagai rumah sakit rujukan tingkat lanjut petugas harus lebih cekatan dan memberikan tindakan yang sepat tanggap dalam menyelesaikan keluhan pasien dan memberikan tindakan cepat pada saat pasien membutuhkan atas permasalahan yang mereka hadapi. 


\section{Hubungan antara Dimensi Jaminan dengan Kepuasan Pasien}

Hasil penelitian menunjukkan bahwa pasien rawat jalan di RSUD Arjawinangun Kabupaten Cirebon Tahun 2015 yang menyatakan kurang baik tentang jaminan pelayanan rawat jalan sebagian besar dari mereka juga menyatakan kurang puas terhadap pelayanan rawat jalan yang diterima yaitu sebanyak 83 pasien $(52,9 \%)$ dan pasien yang menyatakan baik sebagian besar juga menyatakan puas atas pelayanan yang diterima yaitu sebanyak 195 pasien (85,5\%). Dari hasil uji statistik menunjukan bahwa ada hubungan yang bermakna antara dimensi jaminan dengan kepuasan pasien dalam pelayanan rawat jalan di RSUD Arjawinangun Kabupaten Cirebon Tahun 2015.

Hasil penelitian serupa yang dilakukan oleh Penelitian Laila Khairani dengan judul Faktor - Faktor Yang Mempengaruhi Kepuasan Pasien Rawat Jalan RSUD Pasaman Barat Tahun 2014. Hasil penelitiannya menunjukan untuk variable jaminan $(72,8 \%)$ responden menyatakan persepsi jaminan petugas kesehatan baik dan $(27,2 \%)$ menyatakan persepsi jaminan petugas kesehatan tidak baik. ${ }^{11}$ Dan penelitian Fuzna Elsa Ulinuha (2014) dengan judul Kepuasan Pasien BPJS (Badan Penyelenggara Jaminan Sosial)Terhadap Pelayanan di Unit Rawat Jalan (URJ) Rumah Sakit Permata Medika Semarang Tahun 2014. Mendapatkan kesimpulan pada variabel Assurance/Jaminan responden puas dengan adanya jaminan keamanan dan kepercayaan sebesar $51,51 \%$ dan responden tidak puas dalam kemampuan para dokter dalam menetapkan diagnosis penyakit sebesar $14,14 \% .^{12}$

Hasil penelitian ini menyatakan bahwa ada hubungan antara dimensi jaminan dengan kepuasan pasien rawat jalan di RSUD Arjawinangun Kabupaten Cirebon. Dari hasil pengamatan langsung dilapangan asumsi peneliti melihat respon dari responden hampir setengahnya menyatakan kurang baik hal ini bisa ada beberapa kemungkinan yang pertama dikarenakan pasien yang berkunjung ke rawat jalan tiap harinya relatif banyak sehingga petugas lebih fokus untuk segera menyelesaikan tugasnya sehingga melupakan pentingnya sikap ramah dan senyum saat melayani pasien.

\section{Hubungan antara Dimensi Empati dengan Kepuasan Pasien.}

Dari hasil statistik diperoleh $P=0,000(\mathrm{P} \leq 0,05)$ yang menunjukan bahwa Ho $=$ ditolak artinya ada hubungan yang bermakna antara dimensi empati dengan kepuasan pasien dalam pelayanan rawat jalan di RSUD Arjawinangun Kabupaten Cirebon Tahun 2015.

Dimensi ini merefleksikan kemampuan pekerja untuk menyelami perasaan pelanggan, sebagaimana jika pekerja itu sendiri mengalaminya. Hasil penelitian di atas sesuai dengan pendapat Kotler bahwa kepuasan sebagai respon dari pemenuhan harapan dan kebutuhan konsumen. Pendapat ini juga dikemukakan oleh Tjiptono yang mengemukakan bahwa tingkat pemenuhan kenikmatan dan harapan ini dapat lebih atau kurang. Kepuasan adalah fungsi dari perbedaan antara penampilan yang dirasakan dan diharapkan. Kepuasan merupakan persepsi yang dirasakan oleh individu ketika harapan dan kebutuhannya dapat dipenuhi oleh individu atau faktor lainnya. Pasien merupakan salah satu individu yang memerlukan penanganan denagan kemampuan lebih dari petugas kesehatan. Ketika petugas memberikan penanganan kepada pasien sesuai dengan apa yang dibutuhkan oleh pasien maka pasien akan merasa puas terhadap hasil tersebut.

\section{SIMPULAN}

1. Pasien yang merasa puas dengan pelayanan rawat jalan di RSUD Arjawinangun Kabupaten Cirebon sebanyak 69,9\% dan yang tidak puas sebanyak 30,1\%.

2. Ada hubungan antara dimensi bukti fisik dengan kepuasan pasien rawat jalan di RSUD Arjawinangun Kabupaten Cirebon Tahun 2015. Yang menyatakan baik sebanyak 74,0\% 
3. Ada hubungan antara dimensi kehandalan dengan kepuasan pasien rawat jalan di RSUD Arjawinangun Kabupaten Cirebon Tahun 2015. Yang menyatakan baik sebanyak 70,9\%

4. Ada hubungan antara dimensi ketanggapan dengan kepuasan pasien rawat jalan di RSUD Arjawinangun Kabupaten Cirebon Tahun 2015. Yang menyatakan baik sebanyak 65,2\%

5. Ada hubungan antara dimensi jaminan dengan kepuasan pasien rawat jalan di RSUD Arjawinangun Kabupaten Cirebon Tahun 2015. Yang menyatakan baik sebanyak 59,2\%

6. Ada hubungan antara dimensi empati dengan kepuasan pasien rawat jalan di RSUD Arjawinangun Kabupaten Cirebon Tahun 2015. Yang menyatakan baik sebanyak 42,1\%

\section{SARAN}

\section{Bagi RSUD Arjawinangun Kabupaten Cirebon}

1) Manajemen rumah sakit bidang pelayanan medis dan keperawatan bekerjasama dengan komite medis dan keperawatan melakukan evaluasi secara berkala untuk menilai kinerja para dokter dan perawat yang bertugas di rawat jalan.

2) Mengikut sertakan para dokter dan perawat yang bertugas di rawat jalan pada acara seminar atau pelatihan yang dapat meningkatkan kinerja.

3) Melakukan pelatihan teknis kepada petugas terutama untuk meningkatkan dan melatih petugas bagaimana berkomunikasi yang baik dengan pasien sehingga pasien merasa nyaman dan merasa diperhatikan

4) Melengkapi fasilitas di pelayanan rawat jalan untuk kenyamanan dan keamanan dari pasien. Dengan memprioritaskan ketersediaan air bersih di tempat pelayanan maupun WC umum.

5) Menambahkan informasi seputar kesehatan sebagai promosi kesehatan dan edukasi kepada masyarakat, bisa berupa spanduk, poster bergambar, brosur dan lain - lain.

\section{Bagi Petugas Pelayanan Rawat Jalan RSUD Arjawinangun}

Untuk senantiasa meningkatkan kedisiplinan dan terus mengaktualisasi kemampuan dan keahlian pada bidang masing - masing dapat memberikan pelayanan terbaik sehingga dapat memuaskan masyarakat.

\section{Bagi Responden}

Untuk dapat memberikan kritik dan saran kepada rumah sakit berkenaan pelayanan kesehatan melalui kotak saran yang sudah disediakan agar tercipta indeks kepuasan masyarakat.

\section{DAFTAR PUSTAKA}

1. Anonim.Peraturan Mentri Kesehatan republik Indonesia nomor 340/Menkes/Per/ III/2010. [di akses tanggal 10 Maret 2015]. Diunduh dari:http//www.bppsdmk.depkes.go.id

2. Azwar, A. Menjaga mutu pelayanan kesehatan aplikasi prinsip lingkaran pemecahan masalah, pustaka sinar harapan: Jakarta;1996

3. Kotler,Philip \& Kevin Lane Keller. Manajemen pemasaran, cetakan pertama, edisi bahasa Indonesia, Jakarta: PT Indeks; 2007

4. Lupiyoadi,Hamdani. Manajemen Pemasaran Jasa, Edisi Kedua. Jakarta: Penerbit Salemba Empat; 2006

5. Keputusan Bupati Cirebon no. 445/ kep. 25-keu/2010 Tentang penetapan Rumah sakit Umum Daerah Arjawinangun sebagai satuan kerja yang menerapkan pola pengelolaan keuangan Badan Layanan Umum Daerah (PPK BLUD): Cirebon; 2010

6. Freddy Rangkuti. Measuring customer satisfaction. Gramedia Pustaka Utama: Jakarta; 2006

7. Kasubag Humas RSUD Arjawinangun. Pesan pasien melalui kotak saran; RSUD Arjawinangun; 2014 
8. Notoatmodjo, Soekidjo. Metodelogi penelitian kesehatan. Jakarta: PT. Rineka Cipta; 2010.

9. Faizal Maulidhany Rarin. Analisis kepuasan pelanggan terhadap pelayanan pasien rawat jalan Di Rumah Sakit Islam Hidayatullah. Yogyakarta; 2006

10. Tjiptono, Fandy. Pemasaran strategik, Penerbit Andi, Yogyakarta; 2008

11. Laila Khairani. Faktor-faktor yang mempengaruhi kepuasan pasien rawat jalan di RSUD Pasaman Barat. [Thesis].Padang: UNAND; 2011 